\title{
13 Proverbs in Mass Media
}

\subsection{Introduction}

The present chapter explores various aspects of application of proverbs in the English language media texts which is predetermined by the specifics of the mass media discourse. In modern mass media the proverb proves to be a tool of choice for conveying different attitudes and views. The primary resource data include English and American newspapers and magazines, an American TV series, and popular English language songs.

\subsection{Proverbs in the Media Discourse: General Remarks}

The importance of the mass media in the modern societies is indisputable. For many people they serve as the firsthand source of information and, thus, understanding of the world. Their influence is so overwhelming, it is next to impossible to stay unaffected.

The mass media aimed at reaching a wide audience by mass communication encompass a range of broadcast (TV, radio, cinema, recorded music), print (newspapers and magazines), digital (Internet), and outdoor (billboards, placards etc.) vehicles. Thus, media discourse is a multidisciplinary field dealing with a number of overlapping discourses. The mass media include both technical means of transmitting information and people involved in the process (Константинова, 2008: 23). As scholars point out, the key features of the verbal language of human interaction converge and alter in their particular way in the language of mass communication (Володина, 2004: 11).

The task of any author conveying some piece of information through a mass medium is to affect a vast audience. In this respect all the media, print press in the first place, rely heavily on the language used for the stated purpose. Beyond doubt, information delivered to their recipients must not only be of interest and some use to them but also be presented in some special manner as to make it appealing and noticed. The success of a print piece, be it a newspaper editorial or a magazine interview, is in many ways predetermined by the effective choice of linguistic means. It is a bit different case with broadcast media, for they mainly employ visual and/or audio channels of communication. This, however, does not diminish the importance of the language content. The authors of media texts use language freely, creatively, even boldly sometimes. It comes as no surprise that in modern media discourse proverbs 
are one of the preferred tools for conveying a myriad of attitudes, opinions, beliefs, and such.

Apart from influencing the audience, media authors are challenged to transmit substantial pieces of information as succinctly as possible. As tokens of culture and miniature theories (Honeck, 1997: 103) paremias are capable of successfully handling the task. Proverbs serve as contextual cues in discourse, and, therefore, can affect the meaning of the message and its perception. Studies show that application of proverbs is a significant feature of modern mass media discourse (Константинова, 2008). No wonder this field has presented some scholarly interest to paremiologists around the world. It is not our task to review these many researches: Prof. Wolfgang Mieder's most comprehensive bibliography will give an idea of what has been done in the realm of application of proverbs in the media discourse in different European languages (Mieder, 2009).

Let it be once again stressed that modern media texts are permeated with proverbs. Both old proverbs and modern ones, i.e. those with no reference earlier than 1990 (Mieder, 2012: 138), make their frequent appearance in media discourse. Mieder, an outstanding proverb scholar based in Vermont, USA, stated it as a must for paremiologists to "look at which traditional proverbs survive today and which have actually been coined in the twentieth and twenty-first centuries". Media texts can serve as a plentiful and fruitful material for this kind of research (Mieder, 2004: 150). Here are a couple of examples of modern proverbs employed in media texts:

\footnotetext{
Meredith: You're operating?

Richard: I am. A Whipple.

Meredith: That's big.

Richard: I say, go big... or go home. ("I Like You So Much Better When You're Naked” 6-12/ "Grey’s Anatomy")

Oprah Winfrey: During the campaign, how did you handle all the jokes about your husband being "not very smart"? Did it hurt?

Laura Bush: It made me mad, actually-though I didn't hear that many of the jokes because we were campaigning every day. $<\ldots .>$

Oprah: But did the jokes hurt?

Laura: Yes. Coming to terms with the jokes doesn't mean that your feelings aren't hurt or that you aren't miffed, but you learn to take it with a grain of salt.

Oprah: I don't know if you take it with a grain of salt, or with a whole box of salt!

Laura: It does make you feel like things are unfair. But you just know that happens. As they say, if you can't stand the heat, get out of the kitchen. (interview with Laura Bush/ O, The Oprah magazine)
}

Such media discourses as television, popular music, cinematography, and advertising, which is part and parcel of modern mass media, are distinguished as having originated and started the circulation of many modern paremias, as: Diamonds are 
a girl's best friends (the Broadway musical Gentlemen Prefer Blondes) ${ }^{161}$, We're not in Kansas anymore (the movie The Wizard of $\mathrm{Oz})^{162}$, Knowing is half the battle (G. I. Joe cartoon TV series) ${ }^{163}$, Diamonds are forever (the DeBeers advertising catchphrase) ${ }^{164}$. As for the film discourse, certain proverbs (in some cases modified) have even become a kind of hallmark for some motion pictures. Here are just to name a few: $A$ boy's best friend is his mother (<A dog is a man's best friend) (Norman Bates (Anthony Perkins)/ Psycho) ${ }^{165}$, Carpe diem. Seize the day (John Keating (Robin Williams)/ Dead Poets Society ${ }^{166}$, Life will find a way (<Love will find a way) (Dr. Ian Malcolm (Jeff Goldblum)/ The Lost world: Jurassic Park) ${ }^{167}$, After all, tomorrow is another day! (Scarlett O'Hara (Vivien Leigh)/ Gone with the Wind) ${ }^{168}$.

\subsection{Traditional Proverbs in Mass Media}

Proverbs belong to the realm of linguistic and cultural knowledge shared by a nation (or nations, in case of internationally disseminated paremias). In this respect, the employment of proverbs in discourse can be treated as quotation, calling upon for authority and traditional views of the majority. Standard proverbs in their dictionary form do appear in modern media texts, though not as frequently as their transformed variations. Proverbs are autonomous utterances having no bonds with the originating context (i.e. context of the very first use) and no known (or, rather, generally known) author. Proverbs are, metaphorically speaking, in the custody of the people; therefore, by employing one in discourse we can be said to be quoting folk speech. So, one of the issues concerning the standard use of proverbs in the mass media is the way these folklore utterances are placed in discourse. Numerous scholars are engaged in the study of introductory proverb formulas (see Yankah, 1986). In some languages these are set phrases obligatorily used in discourse as a reference to folk culture and tradition. Such introductory formulas frequently occur in the Anglo-American mass media, as well. Their use, however, is not predetermined by cultural tradition but rather pragmatic factors, i.e. the goals and intentions of the author.

In some mass media texts, proverbs are employed as solid statements of apparent truth with no commentary from the author. Such application is consistent with $\mathrm{O}$.

161 http://en.wikipedia.org/wiki/Gentlemen_Prefer_Blondes_(musical)

162 http://www.script-o-rama.com/movie_scripts/m/muppets-wizard-of-oz-script.html

163 http://www.script-o-rama.com/movie_scripts/a2/gi-joe-rise-of-cobra-script.html

164 http://www.phrases.org.uk/meanings/a-diamond-is-forever.html

165 http://www.imdb.com/title/tt0054215/quotes?ref_=tt_ql_3

166 http://www.imdb.com/title/tt0097165/quotes?ref_=tt_ql_3

167 http://www.imdb.com/title/tt0119567/quotes

168 http://www.imdb.com/title/tt0031381/quotes?ref_=tt_ql_3 
Arewa and A. Dundes's theory according to which a person using a proverb is but "the instrument through which the proverb speaks to the audience" (Arewa \& Dundes, 1964: 70). Here is an example from the O. Winfrey's interview with the American R'n'B singer Mary J. Blige:

Oprah: Has your transformation compelled you toward a greater responsibility in your artistry and lyrics? <...>

Mary: $<\ldots>$ After the "No More Drama" album, people came up to me and said, "You saved me. You talked me out of an abusive relationship".<...> A lot of people hate me for this. People say things like "Mary, I liked it better when you were singing them sad songs. $<\ldots>$ You need to pick up a pack of cigarettes and come back down with us”. It blows my mind - then again, not really. They just want someone to waddle with them in their environment.

Oprah: Misery loves company. People identify with the rawness and pain in your music. <...> They have an expectation about you based upon themselves. (interview with Mary J. Blige/ O, The Oprah magazine)

Such cases of bare proverbs are scarce in media texts, which is, in my opinion, a testimony to the fact that application of proverbs in the language of the mass media is a highly innovative and creative process, a sort of exercise in quotation (Yankah, 1986). In general, referring to someone else's words in discourse presupposes a certain attitude (agreement or disagreement) to what is being stated. In a small number of cases media authors, however, introduce a proverb as an epitome of some situation, presenting it as a conventional opinion, and, thereby, remain impartial to what is being said:

Great minds, it is said, think alike. Which must make the Observer's Andrew Rawnsley and the Sunday Telegraph's Matthew d'Ancona the wisest of the wise. (The Sunday Columnists / The Guardian 19/01/2004)

In other cases, the traditional folk view expressed in a proverb is either supported by the speakers and, thus, sounds as their own:

Oprah: I've read that you no longer want people to dress like you. What do you mean by that? Madonna: I mean just that. In the beginning of my career, I was consumed with fashion and the way I looked.

Oprah: Aren't you still?

Madonna: I think about clothes all the time - you see the boots and pants I'm wearing. But who cares? You know as well as I do that clothes don't make the woman. <...> (interview with Madonna/ 0 , The Oprah magazine),

or is claimed to be shared with the audience:

We all know that death is a great leveler and that Princess Diana and Fred West are dead, but that is the only connection between them as far as I am aware. (More than a laughing matter / The Guardian 8/06/2000) 
Proverbs are indeed handy vehicles to address the audience. By applying these folklore dicta, media authors can feel safe as they rely on common knowledge and share the same ground with the intended recipients. Thus, the sense of belonging and intimacy can be easily achieved. Consider the following examples:

Sorry, but it's true - no pain, no gain. If you want to get fit and lose weight, you need to sweat. (Just for kicks / The Guardian 4/10/2003);

In America, the Beg, Borrow or Steal website is a runaway hit, with women signing up for as little as $£ 12$ a month to hire goodies by the likes of Prada, Fendi and Burberry <...> Although more than 700 bags are available on the US site, many are the more basic offerings from the heavyweight fashion houses. But beggars can't be choosers, girls, and if you can't afford to live out the Carrie Bradshaw Fendi bag dream (i.e. owning the real thing), at least you could soon have the option to rent. (Snippets / The Guardian 30/07/2004).

In the majority of cases media authors distinctly express their attitude to proverb wisdom. By commenting on it, they either support it:

Home is where the heart is, to be sure. But home may also be where the money is these days, as Americans put away their dancing shoes and come back home again. At least, that is what publishers of the elite home-design magazines are betting on. (Elite Magazines Compete for a Place at Home / The New York Times 5/11/1990);

\section{or contest it:}

Opening voice-over: In general, people can be categorized in one of two ways. Those who love surprises and those who don't. I don't. I've never met a surgeon that enjoys a surprise, because as surgeons, we like to be in the know. <...> My point is this: whoever said "What you don't know can't hurt you", was a complete and total moron. Because for most people I know, not knowing is the worst feeling in the world <...> (Into You Like a Train 2-6/ Grey's Anatomy);

First things first. Look before you leap. A stitch in time saves nine. Don't put the cart before the horse. Worthy mottoes, all of them, brimming with wisdom. But sometimes such thinking can suck the life out of a project before you even get started". ("Parlor Doors, Outdoors"/ "The New York Times" 21/08/2005);

or contradict it:

They say death is a great leveler. They're wrong. Inequality pursues us after life too. Consider Ground Zero. While international attention has shifted to Afghanistan, the vast project of bodypart retrieval in Lower Manhattan is probably the most exorbitant expenditure on the dead in our lifetime, and yet remains almost entirely exempt from criticism or debate. (The Hierarchy of Death / The Guardian 28/11/2001) 


\subsection{Modification of Proverbs in Mass Media}

Along with standard proverbs encapsulating pieces of folk wisdom, media authors increasingly resort to creative use of these cultural and linguistic gems, which produces sometimes remarkable modifications offering fresh views and different interpretations.

The need for alterations and the quest for something new are perhaps in the human nature. The phenomenon of proverb modification has been observed and attended to by scholars for quite a while now. Recent decades have proved it to gain momentum both in English and Russian mass media. Likewise, the process is widely studied in many other major European languages.

As for Anglo-American media discourse, it can be stated that creative use of proverbs yielding all sorts of nonce modifications is far more predominant than their standard use. Traditional proverbs do occur in the media, but the scale of the modification phenomenon is so extensive that it can be considered a universal method of affecting the audience. Constant changes in life lead to changes in opinions, ideologies, and morals. This inevitably and naturally reflects in the paremiological lore of the language.

The dynamic development which the mass media has gone through at the turn of the twenty-first century has dramatically triggered the aforementioned phenomenon of proverb modification. The modern media can virtually reach vast audiences in all corners of the world, in no time, with messages intended to communicate new cognitive content and, thus, encapsulating new, i.e. non-standard, approaches and views. On the whole, such creative transformations broaden the linguistic boundaries of a given culture, demonstrate novel ways of thinking, and, more importantly, introduce new directions for action. Proverbs can be adapted to any socio-cultural context, and, therefore, frequently modified, immediately come in view of broad audiences with the help of any of the existent mass media.

According to my study the process of proverb modification is predetermined by cognitive and pragmatic factors. These transformations occur due to the necessity to name the yet unnamed, to convey new (or in some cases renewed) cognitive content. The creative use of proverbs enables authors to fulfill the following pragmatic tasks, all of which are indispensible to the principal goal of affecting the mass audience:

1) attention grabbing;

2) expressing evaluations/attitudes;

3) creating stylistic effect, i.e. enhancing expressiveness and emotionality (Константинова, 2008: 87).

Of all the wealth of proverb transformations in the mass media, it is possible to distinguish four groups on the principle of stylistic and aesthetic effects achieved thereby: 
1. Hapaxes, or nonce proverbs (Greek hápax eirēménon - (something) said (only) once). This group is composed of modified proverbs that are (1) context bound, i.e. to interpret them you need originating context, and/or (2) often lack imagery and, therefore, have little aesthetic value and impact potential. Consider the following examples:

Macho man decides: don't get even - get mad (headline)

Tony Blair is evidently upset by the leaking of a memo in which he appeared to demand help at question time.

So yesterday we met the new prime minister, Mr. Mucho Macho Man. When asked the formula question - what his engagements were for the day - he snarled like a home football fan trapped in the visitors' enclosure. "This morning I had meetings with ministerial colleagues and others," he barked. "You got a problem with that?" (Naturally he didn’t say the last bit. But he sounded as if he should. William Hague can count himself lucky that his ear lobes are still intact). (< Don't get mad, get even) (The Guardian 18/05/2000)

Home ain't where his heart is anymore

He may hang his hat behind our bedroom door

But he don't lay his head down to love me like before

Home ain't where his heart is anymore. (< Home is where the heart is) ("Home Ain't Where His Heart Is"/ Shania Twain) ${ }^{169}$.

Izzie: Um, I feel like we should say stuff. Denny, do you want to say stuff?

Denny: Kiss me. Right here. (they kiss) Izzie, that kiss was worth a 1,000 words.

Izzie: A picture. A picture is worth a 1,000 word. (17 seconds 2-25/ Grey's Anatomy).

2. Authorial expressions created on the basis of standard proverbs existing in the language. Such modifications can be seen as the signs of authors' ingenuity and great literary potential. A deeper look at these expressions reveals the way both linguistic and extra-linguistic factors work together in the process of applying proverbs. The worldview of the author, i.e. his/her ideas, opinions, judgments receive such linguistic embodiment which being built from the elements of preformed linguistic material (standard proverbs) appears so creative, original and novel! Here are several examples:

It's like being tired but you just can’t sleep

Your bed is obsolete

It's like finding out the best things in life are free

After you already paid. (< The best things in life are free) (Don't look back / Mxpx) ${ }^{170}$;

Patient: Oh, I'm not his wife. What's that saying - uh, they won't buy the cow if you give 'em the milk for free? Yeah, we're working on eight years of free milk" (<Why buy a cow when you can get milk for free) (Tainted Obligation 6-4/ Grey's Anatomy);

169 http://www.metrolyrics.com/home-aint-where-his-heart-is-anymore-lyrics-shania-twain.html 170 http://www.metrolyrics.com/dont-look-back-lyrics-mxpx.html 
(3) We must call the political tune...

...even if that means paying the piper (headline) ( $<$ He who pays the piper calls the tune) (The Observer 3/02/2002).

The third and the fourth group of modifications are made up of anti-proverbs and pseudo-proverbs, which are amazing instances of creativity and succinctly formulated modern wisdom. They frequently occur in the English language media and, thus, constitute a salient feature of the mass media discourse.

3. Anti-proverbs - that are in fact new proverbs per se created on the basis of traditional ones - are profusely and successfully studied all around the world, major European languages being considered. Anti-proverbs use the elements of traditional paremias but express some different idea. Their meaning is clear irrespective of the originating context. Should you visit Forbes magazine website, for instance, and you will learn a succinctly put strategy of efficient career making, which also happens to be an anti-proverb teaching modern prudence: Snooze, you lose; schmooze, you win (< If you snooze, you lose). In his song Second mouse the American country singer Tim O'Brien resorts to one more astute observation: "It's the early bird that catches the worm, but it's the second mouse that gets the cheese" $(<$ The early bird catches the worm). Film directors and screen writers frequently share their life philosophy through the characters they create. In W. Allen's comedy drama The Purple Rose of Cairo (1985) this is also done with the help of a somewhat careless anti-proverb Life's too short to spend time thinking about life (< Life's short). These are just few of the innumerable examples found in modern Anglo-American media!

4. Pseudo-proverbs. The phenomenon of creating proverb-like formations is quite spread in contemporary English language media. Although these formations are not proverbs, they are built on the basis of paremic structural-semantic models typically with traditional stylistic markers, and express some general ideas often similar to those conveyed by real proverbs. Let us consider some examples:

You can kill the protestor, but you can't kill the protest 4 You can take the boy out of the country, but you can't take the country out of the boy (song title/ Anti-flag);

Every song has its play 4 Every dog has his day (album title/ Gilbert O’Sullivan);

Hand fits giving, so do it 4 If the cap fits, wear it (Sky Fits Heaven/Madonna); Sleep with a snake, you get bit \If you lie down with dogs, you'll get up with fleas (Grey's Anatomy).

Another aspect of creative application of proverbs in the mass media worthy of attention is their multiple use. The phenomenon goes back to the Middle Ages and is tightly connected with iconographic art. In his significant textbook on proverbs Prof. W. Mieder distinguishes a group of poems written wholly in proverbial language, featuring, for instance, Carl Sanberg's famous Good Morning, 
America (Mieder, 2004: 225). An anthology of English proverb poetry came out in 2005, which included lyric poems and song lyrics composed by such outstanding authors as R. Frost, E. Dickinson, A. Bierce, B. Dylan, P. McCartney $\left(15^{\text {th }}-21^{\text {st }}\right.$ centuries) (Mieder \& Sobieski, 2005). The same tendency of bringing multiple proverbs together in one small stretch of text is discussed in the articles by A. L. Macfie and F. Macfie on Turkish poetry (13th - 20th centuries) (Macfie \& Macfie, 1989; Macfie \& Macfie, 2001). The phenomenon has not yet been thoroughly studied. It is possible, however, to distinguish two types of multiple use of proverbs in the mass media, proverb clusters and proverb collages.

Proverb clustering consists in insertion of two or more proverbs (standard or modified) into a non-proverb context. Thus, a blend of proverb and non-proverb texts emerges, as in the song Innocent by Clan of Xymox ${ }^{171}$ :

And it's cold in here when you're all in tears

Your vision is in black and white, you feel so afraid

You fail to show your better half, it's such a shame

Tomorrow's dream never comes, it remains in shades

Remains in shades

Sticks and stones break my bones and it hurts too much

Easy come and easy go, in love and war all seems fair

But it's better to have loved and lost than never to have loved at all

Now I am holding ground

Now I am safe and sound

But it's the last straw that breaks my back and life's too short

Handsome is as handsome does and there's so much more

A change is good as rest they say and all that glitters is not gold

Now I am holding ground

Now I am safe and sound

No way I found love sane and sound

And it's cold in here when you're all in tears

Those endless nights of intrigues make it all too clear

In this dark world and wide I am innocent

I am innocent. (Cf. Tomorrow never comes; Sticks and stones may break my bones, but words will never hurt me; Easy come, easy go; All is fair in love and war; It's better to have loved and lost than never to have loved at all; It's the last straw that breaks the camel's back; Handsome is as handsome does; A change is as good as a rest; All that glitters is not gold).

Other remarkable examples of proverb clustering can be found in a whole set of magazine feature interviews conducted by Oprah Winfrey. The media mogul and experienced interviewer winds up her every interview with some high-profile respondent

$171 \mathrm{http}$ //www.lyricstime.com/clan-of-xymox-innocent-lyrics.html) 
with one and the same question What do you know for sure? It is noteworthy that in every interview the respondents use proverbs in their reply, and occasionally build proverb chains to formulate their thoughts, as does the famous American actress Bette Midler:

That laughter feels really good. That there's a lot of conscious, tangible evil afoot in the world. That the planet will always go on. That you can find peace in nature. That music has great charm and is a great communicator. That dancing is good for the soul. That beauty is very healing and great for the spirit. That you gotta eat a little dirt before you die. That payback is a bitch. And that no matter who you are, there is no free lunch. (<You have to eat a peck of dirt before you die; Payback is a bitch; There is no such a thing as a free lunch).

Proverb clustering is a favorite tool in the American ABC medical drama Grey's Anatomy as well. Opening and closing voice-over narrations frequently play with proverb clusters. Here is one such example of grouping thematic proverbs that help to present the dilemma the main characters are facing in the episode:

Opening voice-over: As doctors, we're trained to be skeptical, because our patients lie to us all the time. The rule is, every patient is a liar until proven honest. Lying is bad. Or so we are told, constantly from birth - honesty is the best policy, the truth shall set you free, I chopped down the cherry tree, whatever. The fact is, lying is a necessity. We lie to ourselves because the truth, the truth freaking hurts. (<Honesty is the best policy; The truth shall set you free; The truth hurts). (Tell Me Sweet Little Lies 2-14/ Grey’s Anatomy)

Proverb collages are entire texts or their structural parts composed of proverbs (standard or modified) and/or sometimes other easily recognized elements, like familiar quotations, proper names, phraseologisms. Stretches of narrator's speech can be occasionally inserted as well. In this type of multiple use of proverbs paremias serve as ready-made material for constructing discourse. Proverb collages are typically found in popular song discourse related to poetic discourse known for this phenomenon since the Middle Ages. Consider the song My Best Was Never Good Enough ${ }^{172}$ by the famous American songwriter and performer Bruce Springsteen:

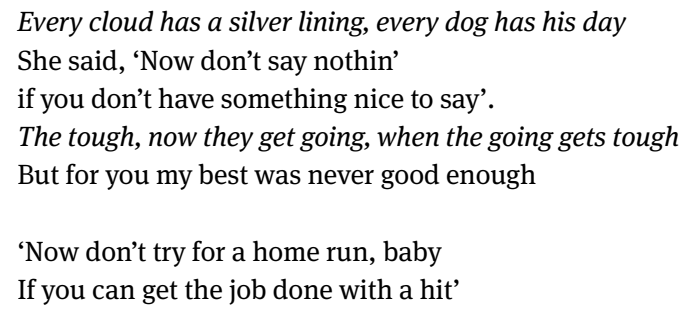

172 http://www.lyricsmode.com/lyrics/b/bruce_springsteen/my_best_was_never_good_enough. html 
Remember, 'A quitter never wins and a winner never quits'

'The sun don't shine on a sleepin' dog's ass'

And all the rest of that stuff

But for you my best was never good enough

'If God gives you nothin' but lemons, then you make some lemonade'

'The early bird catches the fuckin' worm,

Rome wasn't built in a day'

'Now life's like a box of chocolates,

You never know what you're going to get'

'Stupid is as stupid does and all the rest of that shit'

Come'on pretty baby, call my bluff

'Cause for you my best was never good enough.

( $<$ Every cloud has a silver lining; Every dog has his day; The tough get going when the going gets tough; A quitter never wins, a winner never quits; The sun doesn't shine on a sleeping dog's ass; If life gives you lemons, make lemonade; The early bird catches the worm; Rome wasn't built in a day; Life is like a box of chocolates: you never know what you're going to get; Stupid is as stupid does).

Another brilliant proverb collage was created by a female reader of The New York Times as her response to an earlier article, and constitutes her letter-to-the editor with the allusive title The Futile Pursuit of Happiness ${ }^{173}$ :

What? Is Daniel Gilbert saying money can't buy happiness; time heals all wounds; it's the little things that count; look before you leap; act in haste, regret at leisure (Jon Gertner, Sept. 7)? Good lord, what will psychologists think of next? A stitch in time saves nine? (The New York Times September 21, 2003).

\subsection{The Role of Proverbs on the Structural Level of Media Texts}

Proverbs are syntactically complete sentences laden with semantic value, so another important aspect of applying paremias in media texts is their performance on the structural and semantic levels. Of special significance is the role proverbs play in the structuring of texts, be it a newspaper or a magazine article, a TV show episode or a popular song. First, I shall look at their role on the structural level of different media texts.

One of the strong positions of a text is its title. It is a well-established tradition to use proverbs as titles of media texts. Paremias appear in the titles of motion pictures

173 This earlier article by the same title presented the results of a series of experiments conducted by the Harvard Psychology professor Daniel Gilbert and team, who studied how we predict what will make us happy or unhappy and also how we feel after the actual experience. http://www.nytimes. com/2003/09/07/magazine/the-futile-pursuit-of-happiness.html?pagewanted=all\&src=pm. 
(Silver Linings Playbook (2012) (< Every cloud has a silver lining), Fools Rush In (1997) (< Fools rush in where angels fear to tread), All's Faire in Love (2011) (< All is fair in love and war), Money Talks (1997) and TV series (There Is No 'I' in a Team / Grey's Anatomy, Necessity Is a Mother / Beverly Hills (< Necessity is the mother of invention), Out of Mind, Out of Sight / Buffy the Vampire Slayer (< Out of sight, out of mind), All Roads Lead to Fitz / Scandal (< All roads lead to Rome)). Countless examples of proverb titles are found in print press Who pays the piper? (<Who pays the piper, calls the tune) (The Guardian August 37, 2001), A Cultural Reluctance to Spare the Rod; Newcomers Say Americans Spoil Children (< Spare the rod and spoil the child) (The New York Times February 29, 2006), Power corrupts, and how! (< Power corrupts) (The Observer May 1, 2005) and popular songs: You Only Live Twice (Nancy Sinatra) (< You only live once), What Goes Around Comes Around (Justin Timberlake), Practice Makes Perfect (Billie Holiday).

Proverbs prove to be efficient tools for fulfilling the main tasks of the title. Apart from the general function of identifying a work of art, they brilliantly help arouse curiosity of the audience, convey meaning, and provide a summary of the whole text (Gill, 2008: 22-23).

Of all the media discourses considered here popular music is unsurpassed in the scope of the application of proverbs in titles. In some song titles proverbs appear in their standard form, as, for instance, in Elton John's Like Father Like Son, B. B. King's Tomorrow Is Another Day, or Garbage's Silence Is Golden. Applying a non-modified paremia in the title of a song makes it indefinite and, thus, addressed at virtually unlimited number of listeners. In such cases proverb titles depend on other recurrent elements of the song, mainly refrains, to serve as interpretative clues for the audience. More often than not, though, proverbs undergo changes in song titles, which is a natural phenomenon predetermined by the contents peculiarities and compositional characteristics of the song. The most frequently employed modification devices are truncation (When in Rome (<When in Rome, do as the Romans do)/ Billy Joel, None But the Brave (< None but the brave deserve the fair)/ Bruce Springsteen, If Wishes Were Horses (< If wishes were horses, beggars would ride)/ Bryan Adams) and application of proverb imagery (Eye of the Beholder ( $<$ Beauty lies in the eye of the beholder) / Metallica, Spilt Milk (< There is no use crying over the spilt milk)/ Public Announcement, Thorn and a Wild Rose (<Every rose has a thorn) / The Allman Brothers Band). More intricate cases include different instances of allusions All My Roads ( $<$ All roads lead to Rome) / Collin Raye, When the Piper Calls (< Who pays the piper, calls the tune) / China Crisis, word play Jack of All Parades (< Jack of all trades, master of none)/ Elvis Costello, Bitter They Are, Harder They Fall ( $<$ The bigger they come, the harder they fall) / Elvis Presley, and anti-proverbs You Are What You Love ( $<$ You are what you eat) / Jenny Lewis, Men Will Be Boys (<Boys will be boys) / Guy Clark, Someday Never Comes (< Tomorrow never comes) / Brandie Carlile.

For the illustration of the role proverbs play in the structuring of the TV series discourse I shall consider the afore mentioned ABC medical drama Grey's Anatomy, the 
first seasons of which are especially marked by profuse application of proverbs that appear on the local structural level (within the framework of a single episode) and the global structural level (within the framework of a narrative arc). The local discursive elements featuring paremias include episode titles, opening and closing voice-overs, characters' dialogues.

Of considerable interest is the way proverbs function in voice-over narrations. Being an audio-visual system, the film frequently relies on the use of voice-over technique which serves as a unique way of conveying meaning and establishing special relations with the viewers. Therefore, the voice-over narration is not only a significant structural element of the TV series discourse but it also contributes to building its cognitive and content planes. What is being voiced by the invisible narrator in each Grey's Anatomy episode is laden with interpretational value. These opening and closing narrations are perhaps the most crucial parts of the whole episode. When proverbs are employed in them, they help focus the attention of the audience on the information necessary to interpret the meaning of the events and, thus, deduce the message. The episode entitled The Heart of the Matter (4-4) explores the problem of forgiveness or, rather, the ability to forgive. The opening narration contains allusions to two popular proverbs Nothing is certain but death and taxes and To err is human / People make mistakes that help establish the theme of the episode:

\footnotetext{
Opening voice-over: In life, only one thing is certain, apart from death and taxes. No matter how hard you try, no matter how good your intentions, you are going to make mistakes. You're going to hurt people. You're going to get hurt. And if you ever want to recover... there's really only one thing you can say.
}

Character's voice: I forgive you.

The closing voice-over narration summarizes all the events by opposing the traditional proverb providing a seemingly useful piece of advice - Forgive and forget. As the invisible narrator proceeds, it becomes clear that it is sometimes impossible in real life to forgive the ones who hurt us:

Closing voice-over: Forgive and forget. That's what they say. It's good advice, but it's not very practical. When someone hurts us, we want to hurt them back. When someone wrongs us, we want to be right. Without forgiveness, old scores are never settled... old wounds never heal. And the most we can hope for, is that one day we'll be lucky enough to forget.

In the dialogues of the Grey's Anatomy characters proverbs serve as eloquent means of expressing attitudes, i.e. emotional perception of people and events, as in a conversation between two rivaling interns fresh out of med school:

Karev: 4B's got post-op pneumonia. Let's start antibiotics.

Nurse: Are you sure that's the right diagnosis? 
Karev: Well I don't know, I'm only an intern. Here's an idea, why don't you go spend four years in med school and let me know if it's the right diagnosis. She's short of breath, she's got fever, she's post-op. Start the antibiotics. (walks over to Meredith) God I hate nurses. I'm Alex. I'm with Jeremy, you're with the Nazi, right?

Meredith: She may not have pneumonia, you know. She could be splinting, or have a PE.

Karev: Like I said, I hate nurses.

Meredith: What did you just say? Did you just call me a nurse?

Karev: Well, if the white cap fits... (A Hard Day's Night 1-1/ Grey's Anatomy)

Interviewing is considered today as an entertainment rather than information vehicle (Altheide, 2001: 411). This transformation is believed to be caused by "the media logic that has developed since the early days of print journalism”. The main thesis behind this assumption is that a major reason for interviewing being so relevant nowadays is its shift "from an information orientation to an impact orientation that is more characteristic of our media culture" (Altheide, 2001:411). As ubiquitous as proverbs are they play a special role in the structural organization of the interview discourse. I shall start my analysis of the role Anglo-American proverbs play in the interview discourse structural organization with looking at their functioning in adjacency pairs. In a conventional interview communicants orient to the strict question-answer format. In Oprah Winfrey interviews I studied proverbs are used both as questions:

Oprah: Do you think all people are created equal?

Jamie Foxx: No. If that were true, there'd be no poverty, no shortcomings... We're all energy. Some people are stronger forces than others. (< All men are created equal) (interview with Jamie Foxx/ $O$, The Oprah magazine);

and answers:

Julia Roberts: <...> I’ve had people call me with numbers, and I say, “I can't even tell by the tone of your voice whether this is good or bad news”. You just have to let it go.

Oprah: And you have?

Julia Roberts: Whatever happens is going to happen, whether you're sitting by the phone anxious and worried about it or not. (<What's going to happen will happen/ Whatever happens, happens) (interview with Julia Roberts/ O, The Oprah magazine)

In several of Oprah's interviews, proverbs are used in prefaced questions, which help prepare both the interviewee and the audience for the next question, to herald new topics for discussion, thus providing their smooth switch:

Oprah: <...> You've been quoted as saying that fame and money are great, but they don't bring you happiness. What does?

Venus: My family. Laughter. Being able to decide what I want to do. My health. (< Money can't buy happiness) (interview with Venus Williams/ O, The Oprah magazine) 
Celebrity profile interviews as compared with canonical news interviews are notable for the use of continuers, i.e. utterances complementing the question-answer pair and situating "their producer as the intended, and attentive, primary recipient of the talk being produced by an interlocutor" (Hutchby, 2005: 214). In each particular case they fulfill different pragmatic functions, e.g. passing judgments, or evaluating what is being said, as in the conversation with Salma Hayek:

Oprah: $<$... $>$ So you didn't question whether you could or couldn't - it just was?

Salma: I wanted to do films, and at that time in Mexico, a film industry didn't really exist. So where do you go to do movies? You go to the mecca. I also was afraid I was a very bad actress, because I'd become famous very fast and was making money for people. $<. . .>$ I never wanted to be a famous bad actress! I had a panic that people would think, She's good only because everyone knows her.

Oprah: Girl, that's deep! Many would've settled for being a big fish in a not-so-small pond. $(<$ Better a big fish in a little pond than a little fish in a big pond) (interview with Salma Hayek/ O, The Oprah magazine)

\subsection{The Role of Proverbs on the Semantic Level of Media Texts}

It would not be an overestimation to say that newspaper journalists are keen on applying proverbs in their writings. The topics of their articles are indeed multifarious. Political and financial reviews along with sport reports or life and style stories feature all possible proverbs - old and modern, standard and modified. In Oprah Winfrey's magazine interviews, for instance, proverbs support the topics discussed by the famous journalist and her respondents. They include the 9/11 tragedy, personal growth and success stories, life lessons, women's problems, just to name a few. Here is an allusive use of the caution-giving proverb Beware of a silent dog and silent water in the talk with Madleine Albright:

Oprah: Could we have protected ourselves against the World Trade Center and Pentagon attacks? Madeleine: I don't know the answer to that. What most Americans don't know is that we have prevented a lot of terrorist incidents before this one. There's always the dog that doesn't bark that you don't know about. We need to be very careful not to get so into the blame game that we forget those who died. The challenge is to draw lessons from the past and move forward without spending time finger-pointing. (interview with Madleine Albright/ O, The Oprah magazine)

As for popular music discourse, proverbs play a significant role in disclosing the themes of songs. These include love songs and songs addressing social issues. Profuse application of proverbs in both is tightly linked with the task to entertain and affect the listeners' feelings and emotions. Consider the following examples:

"And I believe in helping everybody,

But when it comes to all them foreign loans, 
I think we oughta remember that charity begins at home.

Yes it starts right now in (America, America) <...>” (America, I Believe in You/ Charlie Daniels) ${ }^{174}$;

"Just look him in the eye and simply shout:

Enough is enough

I can't go on, I can't go on no more no

Enough is enough

I want him out, I want him out that door now

Enough is enough

Enough is enough

That's enough". ${ }^{175}$ (No More Tears/Enough is Enough/ Barbra Streisand and Donna Summer)

Some media reveal how widespread in real communication proverbs are. Print interviews, magazine and newspaper articles are live, i.e. non-fictitious, speech. As some of the examples reveal, playful application of proverbs proves to be not only a tool of choice in professional media writing but also in everyday speech that happens to appear or to be quoted in the mass media. This fact is indicative of the universality of the phenomenon and the critical approach to proverb wisdom giving way to reconsideration of old notions and expounding fresh ones.

Media texts serve as a wonderful platform for conveying opinions and judgments with the help of proverbs and about proverbs themselves. Journalists, screen writers, interviewees share their views on the role proverbs play in life. Broadly speaking, these reflections are a mere evidence of how (and to what effect) proverb pragmatic forces are applied in actuality. In the exemplary article Cutting hospital corners (The Guardian Septermber 29, 1999) the author dwells on the problem of contradictory proverbs adding his layman's everyday observations to a great many scholarly studies:

Many proverbs are less axiomatic than they sound. People who murmur sagely that many hands make light work will, when it suits them, announce with equal certainty that too many cooks spoil the broth. He who hesitates is lost, and yet fools rush in where angels fear to tread.

Here's a typical example of how the swindle works. The project to rebuild University College Hospital, London, will "save" £160m in capital costs by using PFI, but for the next 30 years the hospital trust will have to shell out almost $£ 30 \mathrm{~m}$ a year to the developers. In other words, the taxpayer is obliged to pay nearly $£ 900 \mathrm{~m}$ for something that would otherwise have cost $£ 160 \mathrm{~m}$. And, at the end of those 30 years, the hospital will belong to the private consortium. As I have suggested before, it's like taking out a mortgage from a loan shark to buy a house which you already own - and then discovering, 25 years down the line, that the property has been repossessed by the lender anyway.

The end of the article is permeated with proverbial allusions, too:

$174 \mathrm{http} / /$ www.lyricsmode.com/lyrics/c/charlie_daniels/america_i_believe_in_you.html 175 http://www.songlyrics.com/barbra-streisand/no-more-tears-enough-is-enough-with-donnasummer-lyrics/ 
Perhaps such analogies don't mean much to Gordon Brown, who has two handsome residences - 11 Downing Street and Dorneywood - provided free of charge. So let us put it in the sort of language which this connoisseur of proverbs ought to understand: when the PFI goes a-borrowing, our children go a-sorrowing. Or, if you prefer, there's no such thing as the never-never - merely a delayed day of reckoning. (<He who goes a-borrowing, goes a-sorrowing; There is no such thing as a free lunch).

Another article from the Guardian discusses the way proverb authority is exploited in the society:

Most people are brought up by parents who hope to waylay our inherent shallowness with platitudes such as "Beauty is in the eye of the beholder", "A cat may look at a king" and other unlikely bollocks. Given the option, and whatever the circumstances, the majority of us will elect to boff a gorgeous person over a wart-covered hog. <...> But I will concede that, once one knows a person well, it is easier and quite correct that we see beyond their physical appearance. (All the men I've never slept with / The Guardian December 20, 2003)

Here is one more brilliant example of applying several synonymous proverbs to express philosophical reflections that constitute the message of a Grey's Anatomy episode. The starting point for these ideas in the opening voice-over narration is the popular dictum Never leave that 'til tomorrow, which you can do today also serving as a leitmotif for all the happenings in the episode:

A couple hundred years ago Benjamin Franklin shared with the world the secret of his success. Never leave that 'til tomorrow, which you can do today. This is the man who discovered electricity; you'd think we'd pay more attention to what he had to say. I don't know why we put things off, but if I had to guess it has a lot to do with fear. Fear of failure, fear of pain, fear of rejection. Sometimes the fear of just making a decision. Because... What if you're wrong? What if you make a mistake you can't undo? <...>

At the end of the episode the narrator reveals her interpretation of the popular proverb informed by her practical observations. We-narration is used in this case proving this understanding to be shared by many people, the viewers included:

"The early bird catches the worm". "A stitch in time saves nine". "He who hesitates is lost". We can't pretend we haven't been told. We've all heard the proverbs, heard the philosophers, heard our grandparents warning us about wasted time; heard the damn poets urging us to seize the day. Still, sometimes we have to see for ourselves. We have to make our own mistakes. We have to learn our own lessons. We have to sweep today's possibility under tomorrow's rug until we can't anymore. Until we finally understand for ourselves what Benjamin Franklin meant. That knowing is better than wondering. That waking is better than sleeping. And that even the biggest failure, even the worst most intractable mistake, beats the hell out of not trying. $(<$ Time wasted is time lost) (If Tomorrow Never Comes 1-6/ Grey's Anatomy)

Thus, closing the present chapter, I can conclude that the mass media discourse proves to be a really fascinating realm for proverb scholars. Paremias categorize reality by capturing some typical, i.e. recurrent, situations and, therefore, are unique 
ready-made linguistic vehicles for representing similar ones. By doing so, they describe, interpret the world and help express various attitudes. The abundance of these folklore dictums, especially their creative transformations, in media texts testifies to their ubiquity and inexhaustible potential in handling all sorts of pragmatic tasks serving the goal of influencing the mass audience. Much is yet to be explored in this paremilogical field, and it is my hope that the approaches and results offered here can be of help in new scholarly endeavors.

\section{References}

Altheide, D. L. (2001). Journalistic Interviewing. In J. F. Gubrium \& J. A. Holstein (Eds.), Handbook of Interview Research: Context and Method (pp. 411-430). Thousand Oaks, California: Sage Publications.

Arewa, O. E. \& Dundes, A. (1964). Proverbs and the Ethnography of Speaking Folklore. American Anthropologist 66, 70-85.

Gill, P. (2008). "The Name of the Game": Form and Function of Episode Titles in Grey's Anatomy. In C. Burkehead \& H. Robson (Eds.), Grace under Pressure: Grey's Anatomy Uncovered (pp. 22-30). Cambridge: Cambridge Scholars Publishing.

Hutchby, I. (2005). News Talk: Interaction in the Broadcast News Interview. In A. Stuart (Ed.), Journalism: Critical Issues (pp. 210-223). Maidenhead: Open University Press.

Honeck, R. P. (1997). A Proverb in Mind. The Cognitive Science of Proverbial Wit and Wisdom. Mahwah, New Jersey: Lawrence Earlbaum Associates.

[Konstantinova, А.] Константинова, А. (2008). Коммуникативно-прагматический потенциал послович и поговорок в современной англо-американской прессе. Краснодар: Советская Кубань.

Macfie, A. L. \& Macfie, F. (1989). A Proverb Poem by Levni. Asian Folklore Studies, 48/2, 189-193.

Macfie, A. L. \& Macfie, F. (2001). A Proverb Poem by Refiki. Asian Folklore Studies 460/1, 5-19.

Mieder, W. (2004). Proverbs. A Handbook. Westport, Connecticut: Greenwood Press.

Mieder, W. (2009). International Bibliography of Paremiology and Phraseology. Berlin/New York: de Gruyter.

Mieder, W. (2012). "Think Outside the Box": Origin, Nature, and Meaning of Modern Anglo-American Proverbs. Proverbium 29, 137-196.

Mieder, W. \& Sobieski, J. (Eds) (2005). "So Many Heads, So Many Wits": An Anthology of English Proverb Poetry. Burlington, Vermont: The University of Vermont Press.

Yankah, K. (1986). Proverb Speaking as a Creative Process: The Akan of Ghana. Proverbium 3, 195-230.

[Volodina, M.] Володина, М. (2004). Язык средств массовой информации. In M. Володина (Ed.), Язык СМИ - особый язык сочиального взаимодействия (рр. 11-40). Москва: Издательство Московского университета. 